\title{
Olympia 2016: Fakta og Kontrafakta
}

\author{
Af S. Thesenmacher
}

\section{Forspil}

Jeg er blevet bedt om at holde denne forelæsning om De Olympiske Lege i år, her få dage før legene begynder. 2016 er i mange henseender det skelsættende år. I 2015 så vi en debat i Dansk Somahistorisk og Somasociologisk Forening om eliteidræt og Olympismen. Det samme skete i det Globale Forskningsforum for Sport i Toronto i maj 2015. Nu i selve året for De Olympiske Lege i Sankt Petersborg 2016 er det tid til at gøre status, og hvad er nemmere end at sammenligne nutiden med en fjern fortid. Det vil jeg gøre ved at henvise til en artikel af en forfatter, der skrev om Olympismen for 28 år siden. Denne forfatter fors $\emptyset$ gte sig med en futuristisk fremskrivning fra 1988 til 2000. Det er derfor, jeg holder dette foredrag. Vi har på denne måde tre årstal at jonglere med: 1988, 2000 og 2016.

Jeg står med et eksemplar af Idrætshistorisk Årbog fra 1988. Årbogen har et flot omslag, der viser den olympiske fakkel ved åbningen af De Olympiske Sommerlege fra 1976 i Los Angeles, i øvrigt fire år efter den olympiske tragedie i München i 1972. Omslaget kunne have været anderledes. Hvorfor er der ikke et billede af terroristerne i den Israelske Lejr? Ethvert billede fra sportens verden fortæller en historie, og ethvert billede fra de Olympiske Lege fortæller en ideologi.

Bedre end måske noget andet billede vi- ser netop dette billede, at det olympiske motto er, at legene skal fortsætte, uanset hvad der sker. Det er da også sket. Med andre ord taler vi om en robust forside, der på sin egen måde fortæller om den olympiske bevægelses robusthed efter kriser og skandaler frem til i dag. Og billedteksten tilføjer da også, at den olympiske fakkel er bare én af bevægelsens mange myter. Årbogens bidrag er altså skrevet i 1988. Redaktørerne er Jørn Hansen, Per Jørgensen, Bjarne Ibsen og Ole Schøler.

\section{Tema}

Der er en lang række spændende bidrag i det temanummer, som jeg ikke vil kommentere som sådan. Der er dog et bidrag af en vis Søren Damkjær, der fortjener en kommentar på så lang afstand. Dette skyldes især, at dette bidrag er symptomatisk. Artiklen ramte stort set ved siden af, og når den ramte plet, ramte den bare den forkerte plet. De Olympiske Lege er milepæle i sportens historie. Vi ser på Athen $2004 \mathrm{og}$ på 2008 i Bejing. Vi ser tilbage på $2012 \mathrm{og}$ nu 2016. Vi er i Sankt Petersborg. Vi er tilbage i Rusland. Vi er nogle, der husker De Olympiske Lege i Moskva i 1980. Sovjetunionen var en stormagt og en sportsstormagt. En række vestlige lande boykottede legene. Det var pinligt og ydmygende for Sovjetunionen. Ligesom det var pinligt for De Olympiske Lege. Eliteidræt er en mær- 
kelig størrelse. Den krydser den ekstreme idealitet med den mest kommercielle og politiske salgbarhed.

Jeg må sige, at jeg har påtaget mig denne opgave med en vis ydmyghed. Jeg kommer fra en hel anden branche end idrætssociologi og idrætshistorie, nærmere betegnet CogSci. Det er den betegnelse, der har afløst Cognitionsvidenskab. Jeg har dog prøvet at sætte mig ind i feltet idrætshistorie og idrætssociologi. Undskyld betegnelse »felt«, der jo lugter af en forlængst afdød fransk sociolog, der hed Bourdieu. Vi har jo i sociologien og i Cog.Sci. et evindeligt problem med døde filosoffer, døde sociologer og døde ord fra hverdagssproget. Men alligevel vil jeg fors $\varnothing$ ge.

Jeg må henvise til min kollega, dr. Nonsichitian fra Cog.Sci. Universitetet i Erevan. Hans tese er, at sociologien og historien er håbløse videnskaber siden Hegel. Hegels projekt var jo også håbløst. Dette er en forståelig og klar stillingtagen fra en forsker, der som dr. Nonsichitian var opdraget i Marxismen-Leninismen. De jager en fortid, der er fortabt, en nutid der er under dannelse og derfor uforklarlig, og en fremtid, som de ved, de ikke kan forudsige. Så vidt vil jeg nu ikke gå, som det vil fremgå senere. Historien er en meningsform, er dr. Nonsichitians tese. Den kan kun være en fortælling om det, der sker mellem fortid, nutid og fremtid. Et fors $\emptyset$ g eller et skud i tidens tåge på at give fortidige spor, levn, kilder og billeder lidt liv. Men dybest set er historievidenskaben et kreativt skud i skoven eller i det vulkanske bjerglandskab, som er Nonsichitians metafor (eller »blend «, som det hedder i Cog.Sci.) Men altså kun et skud eller snarere en række skud med spredehagl.

Det samme gælder sociologien. Vi har da set så mange fejlskud på det makrosociologiske felt. Den artikel, som jeg henviser til fra Idrætshistorisk Årbog i 1988 forudsagde faktisk Sovjetunionens sammenbrud. Den var således unik, fordi ingen andre historikere eller sociologer havde fantasi til en sådan forudsigelse. Men ser man nærmere på Søren Damkjærs artikel, er den præget af manglende seriøsitet, den er overfladisk. Så ét af de få bidrag, der faktisk ramte plet med hensyn til Sovjetunionens opløsning, kan alligevel ikke tages alvorligt. Her har vi et historiefilosofisk paradoks. Nu er idrætshistorien jo ikke den del af historien, man vil konsultere for at forudsige fremtidens makropolitiske konturer. Idrætshistorien har kæmpet for overhovedet at blive anerkendt. Er somakulturen en prædikator på fremtiden? Det er der nogle, der har hævdet. Men hvorfor skulle somakultur være en prædikator? Kroppen og dens bevægelser kan tillægges enhver mulig og umulig betydning. Det er idrætshistorien et godt eksempel på.

\section{Forudsigelsen}

Hvis vi ser på den olympiske bevægelse og De Olympiske Lege, viser denne Søren Damkjærs artikel fra 1988, at vi er på Herrens mark. (Her har oversætterne åbenbart haft store problemer, fra russisk til tasmansk og endelig til dansk. Det russiske ord har åbenbart været "polje Gospodi«. Udgiverens note). Søren Damkjær fors $\varnothing \mathrm{g}-$ te at fremskrive en udvikling om den globale idræt frem til 2000. Det gjaldt stort set alle centrale faktorer i Olympisk Idræt. Her vil jeg indskyde, at globalisering som begreb stort set ikke var opfundet i 1988. Han forsøgte at se på de former for kropsmodifikation, der var på vej, dvs. genetisk manipulation, der kunne fremavle superatleter. Fåret Dolly var endnu ikke skabt. Men muligheden havde han da øje for. Jeg kan tilføje, at muligheden stadig diskute- 
res, senest ved De Olympiske Lege i Bejing. Søren Damkjær diskuterede også de teknologiske forbedringer af redskaber. Men han så ikke rigtigt det evige paradoks mellem teknologiske forbedringer af udstyr i form af dragter og lignede og forsøgene på at skabe lige vilkår. Også i 2016 vil vi se denne ulige kamp. Jeg vil ikke her lave en lang liste over alle de fejltagelser, der fremgår af artiklen, men nogle af dem vil jeg forholde mig til undervejs. Han opløste som sagt Sovetunionen, som i $\emptyset$ vrigt én af de ganske få forfattere. Men han var ude af stand til at se effekterne af de store samfundsændringer og af de betydende effekter på elitedrætten. Han kunne ikke se, at Sovjetunionens elitesystem efter 1991 ville blive reduceret i det postsovjetiske Rusland. Han så slet ikke spirene til Kinas meget specielle elitemodel bestående af statsstyring og kapitalisme. Det var jo den model, der sikrede Kinas førsteplads ved De Olympiske Lege i Bejing i 2008.

Onde tunger talte om, at Kina havde opereret med genetisk manipulation af atleterne. De havde haft tid at samle alle de faktorer, der skaber topatleter. Men intet kunne bevises. Dopingdjævlen er heller ikke blevet manet $\mathrm{i}$ jorden. Nu var det jo ikke De Olympiske Lege, der for alvor satte denne dagsorden i halvfemserne. Det var den professionelle cykelsport i Europa, der udfordrede den globale eliteidræt og tvang IOC til modvilligt at acceptere et internationalt kontrolorgan, WADA. Som vi ved kæmper WADA her i 2016 stadig en ulige kamp mod udbredelsen af alle mulige »kropsmanipulationsstoffer «. Det skyldes ikke mindst, at disse kropsforbedringsstoffer har fået en så vid udbredelse og accept. Hvorfor skal eliteidræt være en hellig $\varnothing \mathrm{i}$ en verden af forbedrede kroppe? Medicineret kropsforbedring findes på alle områ- der og for alle aldersgrupper. »Trans-kroppe« har fået en hel anden betydning end for 20 år siden.

\section{Det globale samfund 2016}

Vi starter med samfundet 2016, altså nu. På det globale plan er uligheden betydeligt større end i 2000. På 16 år er der absolut ikke sket noget. Vores konference foregår i Sankt Peterborg, som om et par måneder er vært for De Olympiske Lege. Som alle kan se, er sikkerheden i top. De nye sikkerhedssystemer kunne Søren Damkjær ikke forudse. Vores konferencecenter befinder sig i de nye bygninger ved Novij Gavan. Der er kun ganske få, der ved, at det faktisk var centret for Militær Sport i Sovjetunionen. Vi ved, at Forskningscentret for sport befandt sig her, det vil sige TSKAs forskningscenter. Det er i dag faktisk førende i alle mulige former for adgangskontrol. Dette center blev privatiseret i Ruslands kamp mod terrorismen, vi snakker om 2005, og er blevet en lukrativ business. Rusland er endnu ikke et demokrati, men er ledet af en uhellig alliance af et præsidentielt hegemoni og en superkapitalistisk elite, de såkaldte super-oligarker. Men Rusland er verdens sikreste land for afholdelsen af internationale begivenheder. Derfor blev Rusland valgt som vært.

Hvad er nu 12 eller 16 år i den sammenhæng? Artiklen af denne Søren Damkjær er skrevet i 1988. Han ville forudsige begivenhederne frem til 2000. Altså et tidsrum på kun 12 år. Det er her, denne Søren Damkjær tog fejl. Han havde ikke fantasi til at forudsige den utrolige hast og utrolige dybde i den globale udvikling. Og han havde absolut ikke fantasi til at forestille sig den Olympiske Somakultur i 2016.

Fra 1986 til 2000 gik tingene meget hurtigt. Et Sovjetisk Imperium forsvandt, både 
det Sovjetiske med alle dets republikker, »det indre « Imperium, men også »det ydre«, dvs. alle de østeuropæiske satelitter. Et nyt Imperium, Empire Soft, USA, overtog pladsen som det eneste imperium. Siden er det ikke sket det helt store. Europa har ikke formået at skabe nogen overbevisende modpol, heller ikke på sportens område.

Hvordan følger sporten den historiske og politiske udvikling? Godt spørgsmål. Vi har den globaliserede idrætskultur, de globale sportsgrene og OL. Så vidt jeg kan se, er der tale om både synkroni og ikke-synkroni. Den olympiske bevægelse og De Olympiske Lege står ikke uden for verdensudviklingen, men de har nogle særtræk, der gør, at de ikke følger udviklingen. De er langt fra synkrone. Der gik en del år fra kvinderne fik stemmeret, og til at kvinder kunne deltage i Olympisk Sport. Demokratisk har den olympiske bevægelse aldrig været, heller ikke nu i 2016. På trods af de kosmetiske ændringer i ledelsen af IOC, der blev indført for næsten 20 år siden, er der intet sket. Søren Damkjær begik den fejl ikke at se på den organisatoriske kontinuitet i IOC og De Olympiske Lege, men hæfte sig ved mere overfladiske krusninger. Som organisation har IOC vist sig overordentlig robust.

\section{Fejl på fejl}

Jeg vender tilbage til mit udgangspunkt, dvs. Søren Damkjærs artikel, med fare for at gentage mig selv. For 30 år siden forsøgte denne danske idrætssociolog at forudsige den olympiske bevægelses fremtid. På næsten alle områder tog han som nævnt fejl. Han havde åbenbart tænkt dybt over Gorbachovs reformpolitik fra 1985, men han forudsagde ikke DDRs forsvinden. Historien er umulig at skrive på forhånd. Det har dog ikke ført til den store selvransagelse i histo- rien og i samfundsvidenskaben. Der er alt for mange »vested interests $« i$ the Business of History. Og i the business of Sociology. Forskellen på spindoktorer og sociologer er også her i 2016 næsten ikke eksisterende. Her er idrætshistorien og idrætssociologien åbenbart ikke bedre end de såkaldte modervidenskaber; jeg tænker på historien og sociologien. Der er i idrætsvidenskaberne også mange etablerede interesser. De er en del af den forslidte frase om kulturkamp.

På mit konferenceoplæg her i 2016 må jeg mane til besindighed. De Olympiske Lege er blevet bortdømt gentagne gange. Deres undergang har været forudsagt adskillige gange, så længe jeg kan huske. Og dog eksisterer de stadig og har overlevet adskillige imperier og krige. Men hvordan og hvorfor? Jeg kan ikke nægte, at jeg ser det ud fra et lillebitte land, Danmark. Det er mit seneste fædreland, selvom jeg ikke har indfødsret. Vi kæmpede for overhovedet at være med i global elitesport. Vi lavede nye strukturer for eliteidræt. Der kom en helt ny struktur i 2003, stærkt statsstyret, nærmest som i Frankrig. Vi ved, at den ikke producerede resultater. Det så vi 2008 og 2012. I Danmark er idrætten traditionelt en del af en kulturkamp. Jeg vil nævne den kulturkamp, der stadig foregår i 2016. Her vil jeg se på kulturkampen om historien. Hvis vi ser på historievidenskaben i Danmark, blev den genstand for en såkaldt kulturkamp i begyndelsen af årtusindskiftet. Det var kort efter år 2000. Der var en kamp om to ting. Det ene handlede om retten til besættelsestiden i Danmark. Denne kamp var jo ikke ny, tværtimod var det endnu en gang en kamp om retten til den rette fortolkning af historien. Så blev der tilføjet en ny kulturkamp: kulturkampen om den kolde krig. Min forgænger lagde i 1988 megen vægt på systemkonkurrencen. Det er klart, at den prægede den olympiske be- 
vægelse og Legene. Hans bidrag var præget af den kolde krigs problematik, men også af de ændringer, der var på vej. Så Damkjærs bidrag må siges at indskrive sig i en kulturkamp. Jeg tror bare ikke, at han vidste det. Men i 1990 var DDRs sportssystem opløst. Sovjetunionen forsvandt året efter. Så var systemkonkurrencen forsvundet. Den geniale spanske Samaranch lavede den genistreg i 1992 at vride armen om på De Selvstændige Stater i Eks-Sovjetunionen, så de optrådte som et forenet hold. Så var det slut. Damkjær forudså absolut ikke konsekvenserne af disse ændringer. Han formulerede nogle teser, men havde ikke sans for konsekvenserne. Og han så ikke konsekvenserne for De Olympiske Lege, selvom artiklen netop handlede om De Olympiske Lege. Det viste, at det vigtigste for den olympiske bevægelse og de olympiske idræt var kontinuitet. Det vil sige kontinuitet for enhver pris. Damkjærs bidrag er alt for præget af koldkrigstænkning og kulturradikalisme.

\section{Hvad er IOC og OL?}

OL har stadigt sit monopol på en multidisciplinær cyklisk tilbagevendende begivenhed. Det er et faktisk monopol, som ikke kan anfægtes. Det er utænkeligt, at en ny olympisk bevægelse skulle dukke op, eller at en organisation som rival kan etablere sig. Den globale sport er bygget op omkring magtfulde faktiske monopoler. Det gælder også fodbold eller amerikansk fodbold, selvom amerikansk fodbold er lokaliseret til Nordamerika. Kort sagt: globaliseringen har ikke i de seneste årtier rokket ved den fordeling. Sporten er global, men stærkt stratificeret ud fra sportslig styrke. Monopolerne på centrale globale idrætsbegivenheder består i et netværk med mediemonopoler.
Hvordan skal idrætshistorien begribe denne situation? Vi ser tilbage på historieskrivningen om De Olympiske Lege. Den første intellektuelle præstation fra idrætshistoriske forskere var at vise, at de klassiske græske lege stort set intet havde til fælles med de moderne lege. Derefter bestod opgaven i at bestemme de moderne olympiske leges karakter og deres forhold til den politiske og sociale omverden. Søren Damkjærs artikel befinder sig i denne problematik. Han vil fremskrive og forudse. Hans stil og tone lyder lidt postmodernistisk. Den var præget af vis ironi og distance. Måske var han tidligt ude her, jeg ved det ikke. Det er jo 1988. Postmodernismen og dekonstruktivismen havde konsolideret sig i mange kulturvidenskaber, bare ikke i idrætsvidenskaberne. Fremtidige idehistorikere må finde ud af, om vi med denne artikel har det første bidrag med en postmodernistisk synsvinkel på idrætten. Hvad, der er sikkert, er, at vi kort efter årtusindskiftet i 2000 finder nogle nye toner, der stammer fra postmodernistiske strømninger i sociologien. Betegnelsen bliver den Postmoderne Olympisme. Her er starttidspunktet den skelsættende bog om Post-Olympism, der var baseret på en konference in East Jutland i 2002, nærmere bestemt Aarhus på et yndigt sted. Egentlig var ideen god. Men der var stort set ingen, der for holdt sig til temaet »post «. Begrebet post-olympisme er taget fra alle de post-ting, der har været i gang siden sen 70 'erne. Først kom postmodernisme, derefter kom postfeminisme, post-ditten og post-datten. Så man må sige, at post-olympismen kom med som det sidste skud på stammen. Jeg skal sige, at jeg betragter hele denne post-diskussion som forældet her i 2016. De Olympiske Lege og de olympiske idrætsaktiviteter kan aldrig blive postmodernistiske. Post- 
modernisme repræsenterer simpelthen en anden betydningsform.

De Olympiske Lege er bundet til moderniteten. De kan tilpasses og justeres, men de kan aldrig forvandles til en kalejdoskopisk somakultur. Den kan man finde i dette årti på andre områder. De kan sådan set heller ikke æstetiseres ud over den æstetik, der allerede forefindes. De kan naturligvis korrumperes gennem doping og andre former for kropsmodifikation. Olympismen er på godt og ondt fanget i en etisk og politisk problematik, der er dybt moderne, men deler skæbne med det moderne på godt og ondt. Måske er olympismen en moderne relikt, der ikke magter at d $\varnothing$, men heller ikke kan komme ud af sin istidskilde. Alt andet kan ændre sig og transformere sig og antage nye former. Kun ikke olympismen.

\section{Damkjars mikro-prediktioner}

Jeg skal som nævnt spare tilhørerne for en lang liste over fejltagelser i artiklen, men kun anføre de vigtigste. Der kom ingen genetisk modificerede-atleter før år 2000. Der var en vis naturlig selektion, fordi basketspillere giftede sig med basketspillere, fordi de var så høje. Høje kvinder giftede sig med højere mænd. Men det er ikke mærkeligt. Det så vi især i Rusland. Der kom ingen automatisk forældelse af rekorder, selvom massevis af rekorder var produceret med kropsmodificerende stoffer. Den forældelse er i $\varnothing$ vrigt ikke indført i 2016. Det er klart, at sport ikke handler om absolut lighed eller absolut retfærdighed, men om den relevante lighed og den relevante retfærdighed. Nogle atleter er bare bedre end andre og har bedre træningsfaciliteter end andre. Men doping rejste et etisk problem, som endnu ikke er løst. Kønsopdelingen er bevaret. Hvis der er en mistanke om, at én eller anden form for kropslig forskel har betydning, må idrætten opdele. Der findes i dag ikke en samfundsinstitution, der er så stærkt kønsopdelt eksklusionsbaseret som idrætten. Her i 2016 må jeg konstatere, at kønsopdelingen er fastholdt. Især i olympisk idræt. Vi er vendt tilbage til den gamle, om jeg så må sige, makro-morfologiske opdeling. Biologisk set er kønsdifferencen tvivlsom. Og her i 2016 er den klassiske sociologiske tese om sex og gender også tvivlsom. Men i sporten opretholder man forskellen i mangel af bedre. Sporten må i 2016 siges at være en museum for kropskultur. Den opretholder kønsforskellens betydning, selvom diskussionen af dikotomien sex og gender for længst er opløst. Damkjærs artikel fremskriver naivt nogle diskussioner fra 1988 om så fundamentale spørgsmål.

\section{Det kontrafaktiske $i$ idratshistorien}

Selvom jeg ikke har noget stort overblik over den idrætshistoriske forskning, vil jeg mene, at den historiefilosofi, der gør sig gældende, har en forholdsvis simpel opbygning. Det gælder ikke mindst forskningen af den olympiske historie. Den filosofiske model, der gør sig gældende, er forholdsvis simple modsætninger mellem Athen og Nutid, Virkelighed og Ideal, Virkelighed og Myte. Jeg har med vilje skrevet disse modsætningspar med stort, og de udgør også skelettet i de kritikformer, der gør sig gældende. Kritikformer er former for kritik af den olympiske bevægelse, IOC og De Olympiske Lege. Hver kritikform har en kritikbase. Er man meget kritisk, vil man påvise, at de antikke Lege ikke havde meget af gøre med de moderne Lege. Man vil vise, at virkelighed og ideal falder helt fra hinanden. Og man vil demaskere de myter, ritualer og ceremonier, der er en del 
af den moderne olympismes idegrundlag. Omvendt er der også apologiformer, det vil sige former for at forsvare De Olympiske Leges grundlag. Den eneste operative apologiform, der findes i 2016, er, at legene har overlevet og har været en succes, sportsmæssigt og kommercielt. Det er også den eneste, der har været operativ i de sidste 40 år. Uheldigvis har den olympiske bevægelse ikke haft en filosof af en vis status siden sin grundlæggelse. Men disse simple modsætninger er måske for simple. Det viser sig i Damkjærs artikel.

Der er en alt for enfoldig modstilling af nutid (1988) og fremtid (2000). Fortidens historie kan i en vis udstrækning dokumenteres ud fra forskellige kildetyper. Men nye kilder og nye teorier kan ændre opfattelsen. Nutidens kan med betydelig større usikkerhed belyses, men mange kilder er ikke tilgængelige. Det er samtidshistoriens problem. Den skal revideres. Kort sagt lever samtidshistorien et usikkert liv. Men al historieskrivning er usikker på flere niveauer. Hvis der er noget, der er usikkert, så er det fremtidshistorie. Det er det, Damkjær har skrevet. Her er der i sagens natur ingen kilder. Der er sådan set kun teori og spekulation ud fra fortidens og samtidens historie. Så fremtidens historie er så at sige usikker i tredje potens. Det fører mig til nogle bemærkninger om historiefilosofi, også om idrætshistoriens historiefilosofi.

Historievidenskaben bygger på en meningskonstruktion med et vist antal kildebetydninger i bunden. Uden kilder er historien ren konstruktion. Men kilder duer ikke i sig selv. En »kilde« er en betydningsform, der først bliver til en kilde gennem et konstruktionsarbejde. Historie har som bekendt to betydninger. Fortiden som historie som et objekt og historien som viden om historien. Men sondringen er dybt problematisk. De griber dybt ind i hinanden. Gud ske lov har den postmoderne historieskrivning anfægtet denne naive historiske ontologi. Den gamle diskussion om præsentisme og historicisme er simpelt hen død. Det vil jeg begrunde. Historien er en sær videnskab. Jeg vil kalde den en betydningsform, der reflekterer de betydninger, der opstår i mødet mellem fortid, nutid og fremtid. Historien er tidens betydningsform eller rettere tiden som betydningsform. Det gælder også idrætshistorien. Også idrætshistorien handler om to ting: Sport og bevægelseskultur som betydningsform. Nu kan man jo ikke sige, at idrætshistorien er gennemsyret af historiefilosofiske spørgsmål. Men en vigtig problematik i meningskonstruktionerne er det kontrafaktiske i historien. Hvad ville der være sket, hvis eller hvis ikke? Altså hvad ville der være sket, hvis Hitler havde haft atomvåben? Det kontrafaktiske er en nødvendig, men problematisk meningskonstruktion. Der er i forbindelse med OL flere kontrafaktiske spørgsmål. Hvorfor eksister de stadigvæk i 2016? Hvad ville der ske, hvis OL forsvandt eller simpelthen blev afskaffet? Hvordan ville den idrætspolitiske situation være, hvis de havde et fast hjemsted? Så det kontrafaktiske er en nødvendig ingrediens i historieforskning. Det kontrafaktiske retter sig mod fortiden. Det futuristiske retter sig mod fremtiden. Men her er de filosofiske vanskeligheder endnu større, som Søren Damkjærs artikel tydeligt viser. Det er et gammelkendt paradoks, at hvis man kunne opfinde for eksempel en uudtømmelig og forureningsfri energikilde og i dag påvise konstruktionen og de tekniske detaljer, så ville det ikke være fremtid, men nutid. Forskningen i fremtidsscenarier fremviser også det kendte Jules Verne paradoks. Han ekstrapolerede nutidens (hans egen tids) teknologi. Hans raket til månen var en gigantisk kanon.

Nutiden har sin egen betydningsform. 
Det, jeg i denne sammenhæng vil henvise i Søren Damkjærs artikel fra forrige århundrede, er den næsten grænseløse naivitet, der præger den. Den mangler simpelthen en historiefilosofi om fortid, nutid og fremtiden som betydningsformer. Artiklen fremskriver helt naivt nogle forhold i samtiden, altså 1988, frem til 2000.

\section{Globalisering}

Sådan set var Olympismen global fra fødslen. Men selvfølgelig var det en euroamerikansk form. Statssystem og sport fulgtes ad og gør det stadig på et symbolsk plan. Det er nationer, der optræder. Men reelt er forbindelse mellem statstilhørsforhold og atlet brudt for længe siden. Nation og stat optræder kun som spillekort. De er markører for den olympiske illusion og forbindelse mellem atlet, nation og den olympiske repræsentation af idrætsgrene. En anden vigtig ting er, at globaliseringen på sportens område er svær at indfange. Bliver forskellene formindskede? Opstår der flere variationer?

Og hvad er forskellen på en lille forskel og en stor variation? $\mathrm{Nu}$ er halvdelen af japanske sumobrydere fra USA, Europa, Kina og Mongoliet. For 15 år siden var de trods alt kun en minoritet. Jeg kan ikke her gå nærmere ind på globaliseringen problematik her i 2016. Ordet er nærmest helt slidt op. I min videnskab Cog.Sci. bruger vi det overhovedet ikke. Vi har mere raffinerede tankemodeller om den komplekse relation mellem tid, rum, lighed og forskel. Det kan jeg desværre ikke uddybe her.

\section{Humor}

På én eller anden mærkelig måde er idræt og bevægelseskultur (jeg fastholder den gamle betegnelse) humorforladt. Idræt og sport er serious business. Der er naturligvis stadigvæk de bevægelser i små lande (Danmark), der fastholder nogle ideer om social sanselighed og latterkultur. Men der er ikke meget grin i idrætten, ikke meget smil og slet ingen latter. Der er glade miner, når legene er overstået, men jo ikke latter. Sporten er seriøs, take it or leave it. Selv latterkulturens idræt er dødseriøs, det ved vi nu. Eliteidrætten og især den olympiske eliteidræt er dødseriøse størrelser. Jeg benægter ikke, at folk har det sjovt undervejs i træningen. Bevares: nogle ser glade ud. I min ungdom undrede jeg mig altid over de sovjetiske sportsstjerners attituder efter at have vundet. Her havde vi sportsstjerner, der var så vant til at vinde, at der ikke kunne fremkaldes et smil. Smilet og sejrsjublen er en stereotyp, ligeså vel som de arrangerede shows, der indleder legene, og de såkaldte afslappede afslutningsbegivenheder. Selve legene er seriøse. Sporten som helhed er en alvorssag. Det samme gælder gymnastikken i dens forskellige former. Det er $\varnothing$ velser i forhold til en række standarder. Der er ikke meget at grine af. En gang imellem så vi nogle, der græd, når de tabte. Helt fint. Følelser er der, men de er så at sige programmerede i forhold til sporten som form. Der er heller ikke meget at grine af i idrætssociologien og idrætshistorien. Bevares, der er alle de mislykkede forudsigelser. Der er jo heller ikke meget af grine ad i sociologien som helhed eller historien. Serious Business. Marx var ingen grinebider, og Weber heller ikke. Parsons var en umådelig tørvetriller. Habermas var absolut en protestantisk alvorsmand. Det var som om den protestantiske etik forvandlede sig til et filosofisk og teoretisk isdronningepalads i den protestantiske sociologi. Der var ingen plads til følelser og slet ikke til kroppen. Og det gentog sig i idrætshistorie og idrætssociologi, de 
små tvillinger fra de store modervidenskaber.

Søren Damkjær gjorde i 1988 som idrætssociolog sit bedste med sit futuristiske bud på verden og De Olympiske Lege år 2000. Andre på den tid gjorde det ikke meget bedre. Klog af skade skal jeg udlade min forudsigelse af De Olympiske Lege i 2036, i øvrigt et interessant jubilæum.

Men den efterhånden meget gamle artikel er da et godt udgangspunkt for en refleksion her i 2016.

Vi er da blevet meget klogere på De Olympiske Leges fortid, nutid og fremtid.

\section{Litteraturliste}

Damkjær, Søren. OL 2000, Et Tilbageblik. pp. 107116. I: Idrætshistorisk Årbog 4-1988. 



\section{»Folkelig idræt kan ikke sådan måles og vejes «-}

\section{Om festjournalistik eller: Hvordan rapporterer man ikke-olympisk mangfoldighed?}

Af Henning Eichberg

\section{Festen: Idratsjournalistikken har et problem}

»Folkelig idrat kan ikke sådan måles og vejes " - med dette dybe suk karakteriserede en iagttager sit journalistiske dilemma ved den folkelige idræts landsstævne på Bornholm. ${ }^{1}$

Hvis idræt er fest, så udfordrer den for alvor en journalistik, som rapporterer det, der er målt og vejet. Men passer det nu, at idræt er fest?

I præmoderne tider var leg og dans integrerede dele af henholdsvis adelig og borgerlig festkultur. Med den moderne sports opkomst i 1800-tallet blev disse forbindelser mellem idræt og fest løsnet. Idræt blev til et disciplinopdelt system af træning og resultatproduktion. Denne sportificeringsproces devaluerede legens festlige elementer til fordel for sportens produktivitet og regeltræning. ${ }^{2}$ Imens en speciel festjournalistik ikke eksisterer, har en hel profession dannet sig omkring sportsjournalistikken. ${ }^{3}$

Også for den moderne sport har festen imidlertid bibeholdt en vis betydning. Den disciplinopdelte præstationssport bruger festen som en slags supplement til den »normale « idrætsaktivitet, især til at tjene penge for klubben. Arbejderidrætten prøvede at udvikle sin egen $»$ proletariske festkultur«. Forsøgene blev dog ikke no- gen vedvarende succes, måske bortset fra Fagenes Fest. Den olympiske bevægelses fadere arrangerede præstationssporten efter modellen af verdensudstillingerne, men kaldte denne begivenhed for fest og forsynede den med religiøse undertoner. ${ }^{4} \mathrm{Og}$ gymnastikbevægelserne har udviklet festen som element i sin alternative identitet som en blanding af teater-iscenesættelse, gør-det-selv-aktiviteter og folkelig-national massedemonstration, hvor processen er afgørende, ikke resultaterne. ${ }^{5}$ Festen var således det oprindelige udgangspunkt for 1800-tallets danske gymnastikstævne, som startede i 1862 med en skyttefest. ${ }^{6}$

Sport som fest er imidlertid ikke kun erindring og rest fra den præmoderne folkekultur eller et undergrundsfænomen nedenunder den moderne sport. Under senmoderne vilkår, siden 1900-tallets udgang, har eventkulturen fået større og større betydning i kulturens panorama. Mediestrategier og salgsinteresser, visualiseringsteknikker, politiske interesser og populær fascinationssøgen gik sammen i det store underholdningsshow. En »postmoderne festivalkultur « er kommet over os, både i finkulturelle og i popkulturelle sammenhænge. $^{7}$

Idrætsjournalistikken er altså udfordret gennem et »postmoderne « problem. Hvordan reagerer medierne på festen - og hvor- 
dan kunne de reagere? Relationen mellem medierapporteringen og festivalen er et emne både for De Olympiske Lege ${ }^{8}$ og for festiviteter, som er fremvokset af helt andre traditioner som f.eks. den tyske Turnfest og det danske Landsstavne. Hvad er »den gode historie « ved en folkelig idrætsfest, hvis den ikke producerer bemærkelsesværdige rekorder?

Lad os se nærmere på Landsstcevne 2002, som DGI sammen med skytternes DDS arrangerede på Bornholm. ${ }^{9}$

\section{Prastationsjournalistik - resultatet og helten}

»Brasilien for femte gang - For femte gang vandt sydamerikanerne VM-titlen.

Det har ingen gjort ... Tyskland blev sanket 2-0 ...«(TV2 Sporten, 30.6.02).

Idrætsjournalistikkens mainstream har fokus på resultater og stjerner. I dens fremstilling bliver festen reduceret til resultatproduktion. Den objektiverer sig i rekordernes tal og prominente ansigter. Man ved godt, hvad sport drejer sig om - udmærkelse. Alt andet er udenomspynt, en slags pauseunderholdning. Udmærkelsen er målt i centimeter, gram og sekund, omregnet til points og repræsenteret gennem helte.

Udmærkelsens journalistiks har fundet sin ideelle form i resultatlisten, som består af navne og tal. Man kan sammenligne den med børsindberetninger på avisernes finanssider. Hvis vi vil se tal, skal vi kigge i vores dagblads $\varnothing$ konomi- og sportsdele, ikke på kultursiden. ${ }^{10}$

Hvis det drejer sig om en idrætsfest, som ikke er organiseret omkring præstationen, mister journalisten ikke kun sit objekt. Journalisten bliver også ramt i sin egen identitet. Eksperten, som foran studiets snurrende kamera suverænt præsenterer teknikkens, taktikkens og strategiens detaljer - altså produktionseksperten - bliver devalueret.

Er der andet, der kunne være interessant i sport? »Hvem gider se bønder slå kolbøtter? « som den daværende chefkonsulent i Team Danmark, Niels-Christian Holmstrøm, udtrykte det omkring 1990.

Alligevel rapporterede danske aviser og tv-stationer ikke så lidt fra Landsstævnet 2002. Men hvad og hvordan? Det er ikke så nemt at finde et gennemgående mønster i denne journalistik, som kan sammenlignes med præstationsfortællingen - man nørkler snarere mellem diverse materialetyper og genrer. Klassificerer man beretningerne efter bestemte »emner «, får man en særegen pose blandede bolcher: generelle kommentarer om Landsstævnet, begivenhedens $\varnothing$ konomi, de frivilliges indsats, stævnets højdepunkter, deltagerinterviews, vejrrapporter, transportproblemer, enkelte idrætsdiscipliner, socialt liv og fest, politirapporter og skademeldinger etc. ${ }^{11}$ De enkelte emner er relateret til bestemte journalistiske stilarter. Der eksisterer en - kompleks - sammenhæng mellem journalistens genstand og bestemte typer af opmærksomhed, specifikke konfigurationer af journalistisk form og politik. Man kan identificere nogle typiske genrer, som forbinder fokus og stil på hver deres specifikke måder - og som også finder udbredelse i OL- og VM-journalistikken.

\section{At rapportere andre »rekorder« - antalisme}

»Stor lussing til landsstavne - Svigtende deltagelse til DGI's landsstaevne på Bornholm giver million-underskud « (Ekstra Bladet, 14.5.02). 
»Mere end bestået - Det gigantiske efterskolehold med 2287 deltagere fik mere and bestået $i$ skoleårets sidste eksamen « (Jyllands-Posten, 30.6.02).

»Landstcevne slog fodbold. Landsstcevnet gav VM-fodbolden en gevaldig begmand. Ca. 700.000 danskere sad foran skarmen og fulgte torsdagens åbning, mens kun det halve antal fulgte VM-fodbolden samtidig på $D R \ll(B . T ., 30.6 .02)$.

Hvis begivenheden ikke er centreret omkring resultaterne, kan medieinteressen samle sig om »andre rekorder«. Deltagerrekorder kan være en sådan erstatning. Ved landsstævnet 1990 i Horsens deltog 22.523 aktive, 1994 i Svendborg registreredes allerede 41.570, og 1998 i Silkeborg ikke mindre end 45.027. Det fortæller en væksthistorie, og som sådan gentages her rekordernes velkendte vækstmytologi. På Bornholm nåede man imidlertid af forskellige grunde kun op på - eller ned til 19.769 deltagere, familier og gæster medregnet. Det affødte overskrifter i pressen, som sammenlignede tallet med de 40.000, som DGI havde forventet. Deltagerantallets »lussing « blev også diskuteret som $\emptyset$ konomisk problem.

Der er også andre områder, som kan indgå i antalismens fortælling.

En af dem er TV-tilskuertallene. 680.000 seere fulgte åbningsceremoniens transmission på TV2, som foregik parallelt til transmissionen af fodbold VM på DR1. Senere om aftenen så 728.000 seere Verdensholdets opvisning fra Bornholm. ${ }^{12}$ Det var bemærkelsesværdige tal sammenholdt med de 1,5 millioner danskere, som så finalen $\mathrm{i}$ fodbold VM.

Festivalorganisationen DGI spillede kraftigt med på mediernes antalisme-spil. Et modtræk over for det »nedgående« deltagerantal bestod i, at man rettede opmærk- somheden på det kæmpestore hold af efterskoleelever. Med 2.287 deltagere var dette det største hold nogensinde på et landsstævnets græsplæne og udgjorde dermed en anden type af rekord. Hvis ikke vækst i deltagerantal generelt, så var der vækst alligevel.

Også medieopmærksomheden i sig selv kan blive til et felt for statistisk opmærksomhed. DGI's medieafdeling holdt derfor $\varnothing j e$ med artiklernes antal, spalteplads i millimeter, sekunder i TV-transmissioner, bruttolæsere og -seere - og ikke mindst annonceværdien. ${ }^{13}$

\section{Det spektakulores journalistik-begivenheden inden for begivenheden}

»Kongefamilien svigtede landsstavne" (Vejle Amts Folkeblad, 19.7.02).

»Verdensholdet: Sidste aften med kliken« (Jyllands-Posten, 28.6.02).

»Vand, vand og atter vand « (Bornholms Tidende, 1.7.02).

Mere generelt kan journalistikken dreje opmærksomheden hen imod det spektakulære, som ikke lader sig fange i tal. Fortællingen kan fange - eller konstruere - begivenheden inden for begivenheden. Det kan være overraskende hændelser som hooliganisme og vold eller ceremonielle hændelser som royal deltagelse. Landsstævnet på Bornholm leverede ikke rigtig stof til den slags - ingen vold og ingen dronning! Medierne holdt godt nok øje med politirapporterne, men de indeholdt intet nævneværdigt. Hvis dette alligevel blev rapporteret her eller der, så skete det ikke ud fra journalistikkens interesse i det spektakulæres, men ud fra en velfærdskulturelt orienteret mediedækning. Og hverken en repræsen- 
tant fra kongehuset eller statsministeren kastede glans over stævnet, til forskel fra tidligere landsstævner. Der var altså ikke noget, der ville tillokke den kulørte presse.

DGI prøvede på sin måde at spille med på det spektakulæres fascination ved at arrangere midnats-kroket med selvlysende kugler som en »verdenspremiere «. Men det blev ikke det store mediehit. Kuglerne glødede ikke spektakulært nok.

Langt større var opmærksomheden på Verdensholdet. Dets opvisning(er) i rammen af Landsstævnet fik kraftig resonans på TV og trådte frem i avisernes overskrifter.

Der var imidlertid også de uforventede og uønskede begivenheder. Regnvejr, blæst og storm karakteriserede større dele af Landsstævnet på Bornholm. Telte blev blæst væk, folk søgte ly i skolernes idrætshaller, enkelte arrangementer måtte aflyses. Ferieøen viste sig fra en ubekvem side - ganske vist ingen katastrofe, men alligevel ... Her var noget at skrive om.

\section{Problemjournalistik - hvad går der galt}

»Monumenter til Mikkelsens minde - I bedste Samaranch-stil skarper DGI-formanden Leif Mikkelsen profilen $i$ sit sidste regeringsår" (Jyllands-Posten, 11.2.01).

Det spektakulære kan godt have negative træk, der vækker mistanken om »svinestreger « - dette er feltet for problemjournalistikken. Bad news is good news - denne journalistiske lovmæssighed sætter gang i afsløringsjournalistikken, men støder sammen med det kammerateri, som forbinder sportspressen med atleten og sportsbureaukratiet. ${ }^{14}$ Denne investigative journalistik interesserer sig f.eks. for korruption og do- ping, for de kriminelle forbindelser inden for den internationale olympisme og fodboldverdensorganisationen FIFA. Kendt research i dette felt er blevet foretaget af Andrew Jennings ${ }^{15}$, i Tyskland af Thomas Kister og Jens Weinreich ${ }^{16}$ og herhjemme af Lars Werge ${ }^{17}$. Problemjournalistikken er også et hovedperspektiv - skønt ikke det eneste - i det internationale journalistnetværk Sports Intelligence Unit (SIU) og giver dets konferencer - Play the game - en særlig interessanthedsgrad for medierne. ${ }^{18}$ Det sensationelle har skandaløse sider.

Ved Landsstævnet 2002 var der dog ikke meget at hente for den investigative journalistik. Ingen voldsepisoder, kun få situationer med alkohol-overforbrug, kun enkelte idrætsskader, ingen seksuelle overgreb, hverken doping eller korruption ...

Avisen Jyllands-Posten havde tidligere ud fra en borgerlig-konservativ holdning rettet kritisk opmærksomhed på det pres, som DGI lagde på landsstævnebyernes myndigheder angående investering $\mathrm{i}$ landsstævnestadier. I denne sammenhæng sammenlignede avisen DGI-formanden Leif Mikkelsen med Antonio Samaranch, den berygtede »godfather « for den olympiske korruption. Lignende problemer prægede imidlertid ikke nævneværdigt stævnets mediebillede i 2002, skønt journalister fandt kritiske punkter i stadionbyggeriets kommunalpolitiske og økonomiske realisering. ${ }^{19}$

\section{De glade ansigters} journalistik - jubel og velfard

»Livsglade til Landsstavne - Byger, blast og fest for fallesskabet « (Ungdom \& idraet, 11.7.02).

»50.000 timer fra hjoelperne fär L-2002 til at køre«(Bornholms Tidende, 27.6.). 
»Landsstavne står for leg, glade og facllesskab. Set med internationale фjne kniber det med fallesskab. Men når natten falder på, fungerer det« (Politiken, 30.6.02).

Den positive side af det spektakulære præsenteres gennem de glade ansigters journalistik. Folk er glade i festen - dette bliver udtrykt gennem solstrålehistorier. Folk kigger smilende i kameraet og siger: »Der er gang i den« og: »Det var så sjovt «.

Men formidlingen af disse positive stereotyper og deres blomstrende gentagelse støder ind i et problem: Vil læseren værdsætte dem - kan seeren bruge dem til noget? Som en journalist engang spurgte, svarende til Holmstrøms nedsættende bemærkning: »Tror du virkelig, at folk vil se alle disse glade husm ødre?«

Alligevel har denne type journalistik et publikum. Fortællingen udfolder sig i to hovedformer.

Jubeljournalistikken bliver typisk anvendt af festivalorganisationen selv. DGI's tidsskrift Ungdom og idrat, som ellers er kendt for sin kritiske rapportering, udgav umiddelbart efter stævnet et temahæfte, som gennemgående dokumenterede begivenhedens glædelige sider. ${ }^{20}$ Journalister fra det lokale blad Bornholms Tidende producerede fire udgaver af en farvestrålende Landsstavne-Avisen. ${ }^{21}$ Og DGI og Bornholms Tidende gik sammen om at udgive to varianter af en billedbog. ${ }^{22}$ Den står med sine farverige fotografier $\mathrm{i}$ traditionen af jublende erindringsbøger fra gymnastikstævnerne, som går langt tilbage i historien. ${ }^{23}$

Det samme mønster, men i langt større målestok, er kendt fra de rigt illustrerede bind fra Deutsches Turnfest, udgivet af Deutscher Turner-Bund. ${ }^{24}$ Jubellitteraturen af lignende slags er også kendt fra De Olympiske Lege.
Parallelt, men ud fra andre motivationer, beskriver også en pædagogisk og velfærdspolitisk interesseret journalistik stævnets lyse sider. Festens »gode historie« drejer sig især om fællesskab og de frivilliges engagement, som viser civilsamfundets smilende sider.

\section{Human touch journalistik- det menneskelige og situative}

»Fallesskab og oplevelse. Jørn Madsen skal til landsstavne for 10. gang" (Bornholms Tidende, 27.6.02).

»Veteraner: Hverdagens idratslige helte«(Jyllands-Posten, 28.6.02).

» $\varnothing$-fodbold: Ned at kure for Gurre Frosne kyllinger, kolde pilsner og regn $i$ stonger kan ikke fjerne humøret fra fodboldturneringen $i$ Nexф under DGI's landsstavne på Bornholm « (JyllandsPosten, 29.6.02).

»Kunstigt ben er ingen hindring. Morten Kargo fra Viborg er til sit syvende landsstavne ...«(Bornholms Tidende, 1.7.02). $» \AA ̊ h$, disse minder ...«(Aktuelt, 29.6.98).

Uanset om journalistikken er kritisk eller jublende, så har den mulighed for at nærme sig de konkrete mennesker, der deltager $\mathrm{i}$ festivalen. Her ser man enkelte personers individuelle ansigter, og både den »sære« og den »almindelige« dansker får ordet. Når journalisten interviewer en tilfældig deltager om hans eller hendes personlige erfaring og biografiske baggrund, får det partikulære farve og mellemtoner. Der er ikke noget som menneskets »normalitet« eller »hr. og fru Jensen«. Nuancerne i tilværelsen får ansigt.

Denne genre imødekommer behovet for at komme hinanden ved. Fortællingen er opbygget omkring det menneskelige an- 
sigts dybere betydning for recipienten human touch.

Også lidt sære begivenheder på festens yderkanter kan indgå i journalistens fortælling - overraskende situationer »med ansigt«. Den anekdotiske metode kan noget, som andre genrer - rekordfortællingen, investigativ kulegravning, politisk problematisering - næppe kan: Den skaber - kort og godt - stemning. Denne type af journalistik er især typisk for lokale blade og regional tv.

Den situative journalistik indeholder også muligheden for at vise en vis ironisk distance. Denne metode anvendte JyllandsPosten på Bornholm. Bladets udsendte journalist, Henrik H. Brandt, leverede causerende små historier. De kunne, set i lyset af avisens generelt borgerlig-konservative og olympisk-sportslige orientering, læses som en politisk-ironisk distancering fra den folkelige idræt, men også som en frit svævende ironi, der prøvede at nærme sig den $» r \varnothing r e n d e \ll$ stemning. Historier med et human touch er åben for forskellige fortolkninger.

\section{Showets fortalling - underholdningens blik}

»Stcevnem $\phi d e-40.000$ forført af drømmestemning ved åbningen af gymnasternes landsstoevne " (Ekstra Bladet, 28.6.02). »Åbning i rodt og hvidt - DGI's landsstcevne fik en traditionel og vellykket åbning på et fyldt landsstcevnestadion $i$ Rønne« (Jyllands-Posten, 28.6.02).

„Det var bare så flot. Vi måtte alle overgive os. Landsstcevnets festaften afvabnede os. Vi l $\phi b$ tor for superlativer « (Bornholms Tidende, 29.6.02).

$»$ Egte festivalstemning. Fallessang med Shubidua...« (Bornholms Tidende, 1.7.02).
Vender man sig fra den »lille historie « til den »store «, så møder man showet, især ved åbnings- og ved afslutningsceremonien. Den storartede, glitrende iscenesættelse fanger opmærksomheden. Festival-organisationer bruger gerne kendte pop-kunstneres berømmelse for at kaste stjernedrys over begivenheden. Når prominente ansigter fra underholdningsindustriens scener smiler til publikummet og til kameraet, kan man regne med en bestemt offentlighedseffekt.

Ved Landsstævnet 2002 oplevede man faktisk flere landskendte rock- og popgrupper, først og fremmest Shubidua, Safri Duo, Sorten Muld og Stig Rossen. Deres optræden på landsstævnestadionets scene var et stort tilløbsstykke, og stævnet nærmede sig dermed en rockfestivals attraktivitet. Men der var indholdsmæssig sammenhæng mellem stjernerne og stævnet. Hvad den politiske stemning angår, så spillede Shubiduas særegne anarko-nationalisme godt sammen med stævnebaglandets »folkelighed «, og dette fandt sin form i fællessang hen over generationsforskellene. Safri Duos rytmer var også velkendte hos de mange - talrige gymnastikhold bruger rytmerne i det daglige. Festaftenen var et mytologisk-teatralsk gesamtkunstværk, som var musikalsk gestaltet af Sorten Muld, som i 2001 havde fået højskolernes »den folkelige sangs pris«. Ellers holdt stævneorganisationen sig tilbage fra at overbetone underholdningskulturel stjernedyrkelse, og åbnings- såvel som afslutningsceremonien var friholdt fra brug af popkulturel prominens.

At gymnastikfesten godt kan flytte sig et skridt videre, viser den tyske Turnfest. Gennem de senere år er det tyske gymnastikforbund DTB gået i samarbejde med regionale $\mathrm{TV}$-selskaber for at producere et centralt galla-show som festivalens højde- 
punkt og som et særligt tilløbsstykke. ${ }^{25}$ Det ligger ikke så fjernt fra bestemte tendenser inden for rekordsporten, som betjener sig af underholdningskulturelle indslag for at pynte cirkusshowet.

Underholdningsgenren har sine begrænsninger. En af dem ligger i dens sanselige prioritering af det visuelle. Som Bornholms Tidende udtrykte det: Vi mangler ord - kig derfor på billederne. Festivalens visuelle kvaliteter træder især frem i fugleperspektivet. Farverige fotografier og film er passende midler til denne kommunikation. ${ }^{26}$ Fjernsynet bliver her til hovedmedium. $^{27}$

Denne ensidighed af det visuelle volder imidlertid visse problemer. Et af dem er, at billederne af de farverigt uniformerede masser (foran popstjernen eller lederen på scenen) kan give associationer til fascistiske massearrangementer og til idrættens spartakiader fra sovjettiden (med de »højt elskede ledere« på tribunen). Det ensidige tilskuerperspektiv kan bevirke, at man overser, at stævnets egentlige dynamik kommer fra selvaktiviteten nedefra. Alle deltagere er aktive på en eller anden måde - dette særtræk af den folkelige idræts landsstævne kan hurtigt forsvinde under showets panoptiske perspektivering.

Desuden er der andre sanseaspekter involveret, der er mindst lige så vigtige som det visuelle: Hvad folk hører og fornemmer. Stemning og stemtheden - atmosfæren - er etymologisk forbundet med »stemmen«. Gymnastikken er akkompagneret af pop, rock og funk, men er også i sig selv en slags kropslig musik og rytmik. At mængden klapper i takt, er et særegent element af landsstævneoplevelsen, en hyldest til dem på græsplænen - og til sig selv. Masserne sendte til forskellige lejligheder bølgebevægelser rundt over græsvoldene og tribunerne. Fællessang karakteriserede den folkelige idræts iscenesættelse - også på Bornholm. Rockmusikken rungede fra festteltene og fra friluftskoncerter. Landsstævnesangen af gruppen Ordentlige Folk og Louise Støjberg blev bevidst brugt som jingle og spillet over højtalerne igen og igen, indtil den blev til en ørehænger.

Mere end dette: Det folkelige stævne består af situationer af kollektiv begejstring. I mediernes sprog beskrives det som »feber « eller det »at få gåsehud «. Denne atmosfæriske dimension af festen kan altså omskrives i metaforiske ord, men stemningen unddrager sig show-journalistikkens visualiseringsstrategier.

\section{Kulturjournalistik - ironi, drøm, udfordring}

»På klippegrund: Et rørende landsstavne. Ingen - bortset fra håndboldspillerne $i$ Akirkeby - kan deltage $i$ en landsstavne uden at blive rort. Også Jyllands-Postens udsendte har nu oplevet det folkelige mфde på egen krop « (Jyllands-Posten, 30.6.02).

Den folkelige idræts kulturelle dimension betyder, at idrætten er integreret i folks liv på en bredere eller dybere måde. Men hvordan kan festivalens »ånd « og atmosfære sættes i eksplicit forbindelse med det praktiske liv i hverdagen? Hvordan kan festens demonstrative og bevidste distancering fra hverdagen tematiseres? Her bevæger medieomtalen sig ind i spektrummet mellem kulturel udfordring og medieindustriel underholdning.

Kulturjournalistikken har mulighed for at åbne for, stille spørgsmål ved og kaste lys på de poetiske sider af menneskenes fællesskab. Tilnærmelsen til disse bredere og mere komplekse kvaliteter af idrættens 
fest kan ske ad meget forskellige veje. Nogle af dem kan belyses via en præsentation af de forskellige kulturskribenter, der har tematiseret Landsstævnet 2002 eller andre idrætsfester.

En gangbar vej er det ironiske causeri. Jyllands-Postens udsendte, Henrik $\mathrm{H}$. Brandt, snakkede ironisk om »det rørende« ved landsstævnet på Bornholm og indsamlede pudsige hændelser, vittige situationer, sjov og ballade. Dermed gjorde han opmærksom på, at det »at røre sig « i den folkelige fest er noget, der bringer emotioner frem, rørelse, latter og måske ligefrem tårer. Du kan også møde kærligheden - eller opleve sære situationer med hunde og får ...

Mere yderliggående er Anders Lund Madsens vej. Fjernsynsklovnen var til stede på Bornholm, som han var i Sydney OL $\mathrm{i}$ året 2000. Journalisten går rundt blandt folk, tæt på begivenheden, og stiller dumme spørgsmål. Han kan til tider stille sig helt tåbeligt an, ligefrem gøre en dyd ud af dumheden, og så kan sjove og oplysende sider af begivenheden træde frem. Men showet kan også ende i rent pjat, pladder og pinlighed. Plathedens vej har en solid baggrund i dansk folkelig humor - skønt langt fra alle danskere værdsætter denne slags underholdning.

På en helt anden måde går Jørgen Leth til værks. Journalisten og forfatteren beskriver leg og bevægelse ligesom Tour de France og andre enkeltbegivenheder af olympisk karakter i seriøse, filosofiske og lyriske termer. Det poetiske træder frem, sportens romantiske sider. Nogle gange bliver denne vej kritiseret for, at dens relativisme forbliver alt for affirmativ og ligger tæt op ad det upolitiske supporter-perspektiv. Men gennem poetiske midler fanger den begivenhedens eksistentielle sider: konkretheden og letheden, flygtigheden, drømmen. ${ }^{28}$
Så er der Sørine Gotfredsens vej. Iagttageren nærmer sig sit emne mere analytisk og kritisk. Hun åbner synet hen imod fænomenets kulturelle horisont, gerne provokerende og gennem usædvanlige og overraskende sammenligninger med kulturelle figurer og sociale praktikker uden for idrætten. Det komparative er en vej af at nærme sig - ved samtidigt at tage afstand. Der er liv udenfor avisernes sportssider, og netop dette liv giver profil til det, der foregår på sportens felt. ${ }^{29}$

Og så er der Torben Ulrichs vej. Iagttageren går direkte ind $\mathrm{i}$ begivenheden og bliver gennem en overraskende personlig konfrontation en del af det, der foregår. Iagttageren er selv en happening - hverken som kritiker eller som analytiker eller som supporter, men som personlig udfordring. Ved at iagttage iagttageren - Torben Ulrich - $\mathrm{i}$ begivenheden, begynder man pludselig at se begivenheden $\mathrm{i}$ en anden, uforventet belysning. ${ }^{30}$

Eller er landsstævnet alt for traditionelt til den slags intervention?

De mere udfordrende typer af kulturjournalistik er sjældent blevet brugt i forbindelse med landsstævner. Set ud fra den folkelige idræts selvforståelse - idræt som kultur - burde den måske være hovedgenren?

\section{Politisk journalistik - konflikten}

»Olympisk folkelighed - ... Landsstoevnerne skal bestå, men der bør vare slut med dette ressourcespild « (Jyllands-Posten, 12.2.01).

»DGI's erobringer med den trojanske hest. Naivt og ansvarsl $\phi$ st er de bedste betegnelser for den betonideologi og det hykleri, der får DGI til at sende elite- 
gymnaster rundt med verdensholdet uden et behandlingssystem « (Frits Christensen i Jyllands-Posten, 1.7.01).

»Tid til tømmermand - ... Nappe en eneste af de 15.519 tilmeldte deltagere rejser hjem med en dårlig helhedsopfattelse, selv om en stiv kuling og voldsomme regnbyger gjorde sit til at $\phi$ delagge moralen rundt omkring $i$ teltlejrene ... DGI bør benytte den bornholmske фretoeve til selvransagelse og til et opgør med den tomme del af retorikken og den uhensigtsmaessige del af traditionerne ... Er der ikke noget rivende galt, når man trods denne udskrivning og fire års intens markedsføring alligevel ikke kan formå mere end eksempelvis 48 svømmere, 20 basketballspillere, 42 udøvere af kampidrat og 72 atletikudøvere $i$ at rejse til Bornholm? ...

Selvgodheden har laenge truet med at tage overhaind $i$ en organisation, der $i$ egen forståelse reprasenterer den lokale idrcet, men mest profilerer sig på prestigeobjekter som DGI-Byen, Verdensholdet og det kostbare landsstcevne" (Henrik H. Brandt $i$ Jyllands-Posten, 1.7. 2002).

Sidst, men ikke mindst, er festjournalistik også politisk, det vil sige, at den er på sporet af relevante samfundsmæssige konflikter. Gennem 1800-tallet havde folkeidrættens fester nationaldemokratiske og oppositionelle undertoner og tiltrak sig dermed politisk opmærksomhed. Forskellige former for gymnastik - svensk versus tysk stod for forskellige slags orienteringer i det politiske. I 1930'erne, ved landsstævnet i Ollerup, rykkede begivenheden ind i den internationale fascismes strålingsfelt. ${ }^{31}$ Efter 1945 var der igen lagt op til konflikt mellem forskellige gymnastikformer og mellem forskellige holdninger til nationa- lisme og demokrati. ${ }^{32}$ Fra og med 1968 revolterede dele af den unge generation, og dette fandt sit udtryk på nogle højskoler, dog næppe i idrætsfesterne.

I hvert fald betyder folk i bevægelse, at der er konflikter i folket. Dette er den politiske journalistiks felt. Hvor er landsstævnets sted i nutidens konflikter? Hvordan er det relateret til de aktuelle sociale bevægelser? Hvilken rolle spiller ideologi i festens begivenhed?

For nogle år siden konstaterede en skarpsynet journalist på et landsstævne tilstedeværelsen af en $\gg$ blød kvindelig nationalisme $\ll^{33}$ - til hvilke modsætninger henviser dette?

Hvis landsstævnet var direkte antiolympisk, ville konfliktsituationen være en del klarere for den journalistiske iagttager. Der ville være et enten-eller. Men Landsstævnet, sådan som det tog sig ud på Bornholm, var ikke så enkelt.

Tidligere holdt Poul Albret på Dagbladet Information øje med landsstævnet i en blanding af politisk-kritisk og kulturel journalistik. ${ }^{34}$ Men i de sidste år er det $J y l$ lands-Posten, som oftest har beskæftiget sig med landsstævnernes politiske dimensioner. Avisen prøvede - først og fremmest gennem redaktøren Frits Christensens pen - at konstruere klare fronter mellem olympisk sport og folkelig idræt, til den førstnævntes fordel. Folkelig idræt og dens stævner blev kommenteret i nedvurderende termer ved blandt andet at henvise til stævnets »olympiske folkelighed « som et selvmodsigende paradoks. Dette faldt i tråd med bladets skarpe udfald mod den folkelige idræts repræsentanter - først og fremmest DGI-formanden Leif Mikkelsen. Også idrætsforskningen, som forholdt sig kritisk til den olympiske sports logestruktur, dens funktionærer og deres interessepolitik, blev mødt med aggressive ord. ${ }^{35}$ 
Svarende til avisens generelle linie som borgerligt-konservativt kampblad afviste den olympisk orienterede sportsredakt $\varnothing r$ at tage idrættens mangfoldighed til efterretning. Foran denne baggrund kunne man være fristet til at læse Jyllands-Postens kritisk-ironiske beretninger fra Landsstævnet 2002 som en del af kulturkampen.

Så enkelt var det imidlertid ikke for Bornholms vedkommende. Jyllands-Postens fortællinger fra landsstævnet var så detaljerede og facetrige, at de også kunne læses som en revidering og nuancering af den traditionelle konfrontation. De pegede snarere på visse reelt eksisterende indre spændingsforhold i den folkelige idræt.

Modsigelserne mellem den folkelige selvorganisering nedefra og organisationen ovenfra $\mathrm{i}$ »folkelighedens « navn udgør en central konflikt inden for landsstævnet og den folkelige fest mere generelt. Forholdet mellem folkebevægelsens praktiske dynamik og massernes geometrisk-koreografiske iscenesættelse lægger op til kritisk diskussion. Det samme gør relationen mellem foreningens folkelige gymnastik og Verdensholdets elitegymnastik. ${ }^{36}$

Andre spændingslinier kunne bemærkes mellem den folkelige idræts forskellige aktivitetsformer. Gymnastikken har traditionelt domineret landsstævnernes billede, hvilket tidligere har givet stof til kritiske bemærkninger. ${ }^{37}$ Ubalancen mellem aktiviteterne kom også på Bornholm til udtryk, måske endnu mere end før. Dels bevirkede stævnets geografiske fordeling over hele $\varnothing e n$, at de ikke-gymnastiske aktiviteter blev marginaliseret og gymnastikkens centrale position i Rønne styrket. Og dels styrkede mediebilledet og dets visuelle bias den eksisterende ubalance. ${ }^{38}$

Et yderligere felt af sammenst $\varnothing \mathrm{d}$ er festens $\varnothing$ kologi. Ved Landsstævnet ' 98 i Silkeborg havde DGI valgt at markere en »grøn dagsorden « ved at plante en landsstævneskov efter begivenheden. Skoven skulle bevidstgøre stævnets energiforbrug og sammen med sund mad, genbrug af materialer og salg af træbadges skabe ny bevidsthed om miljøet. Dette skete samtidig med en styrkelse af natur- og friluftslivet på aktivitetsplan. ${ }^{39}$ På Bornholm blev et oplevelseslandskab etableret som »den grønne ring « ved landsstævnestadion i Rønne, ${ }^{40}$ men ellers var den grønne dagsorden forsvundet ud af billedet.

Og så lagde forholdet mellem det rødhvid-nationale og det mellemfolkelige op til overvejelser. Som Politiken konstaterede, kneb det med fællesskab i forhold til de internationale deltagere. Den gode intention var der, både hvad angik deltagelsen af grupper fra fjerne lande - formidlet gennem International Sport and Culture Association ISCA - og af indvandrerhold. Men det internationale telt fungerede snarere som en slags niche, imens stævnets iscenesættelse i sin helhed ikke bidrog til synliggørelse af den mellemfolkelige udfordring.

Politisk journalistik bør være mere end journalistens udlægning af sin egen mening som »den korrekte mening «. Alligevel er journalistikkens eksplicitte stillingstagen legitim. Og mere end dette. Den er et vigtigt element i festjournalistikken. Det politiske perspektiv vækker opmærksomheden for konflikten. Den folkelige fest som folkelige bevægelser har godt af politisk kritik. Festen er ikke kun harmløs.

Le sommeil du volcan, c'est la fête folklorique. Ne vous y fiez pas. Son reveil, c'est la barrage de routes et la défenestration du sous-préfet. Chaque chose à son temps.

»Den folkelige fest er en vulkan, der sover. Føl dig ikke for sikker. Når vulka- 
nen vågner, er vejene hurtigt barrikaderet og politipræfektens vinduer i stykker. Hvert til sin tid. $\ll^{41}$

Således pointerede den bretonske forfatter og folkeforsker Pierre Jakez Hélias folkefestens eksplosive potentiale. Han sagde det med positive undertoner under indtrykket af den franske maj 1968 og den uro, der fulgte i Bretagne. Også da muren faldt i 1989, spillede folkefesterne i Østeuropa og Mellemasien en bemærkelsesværdig rolle, helt fra tatarernes idræts- og forårsfest ${ }^{42}$ til de baltiske folks »syngende revolution $\ll^{43}$.

\section{Kamera og demokrati}

Overblikket over de journalistiske genrer viser et rigt spektrum. Mønstrene er ofte blandet sammen og overlapper hinanden. Visse stilarter og opmærksomhedsformer er også anvendt på olympiske begivenheder, mens andre er mere specifikt relateret til ikke-olympisk idræt.

Ingen af festjournalistikkens genrer er illegitim. Men de udfordrer den journalistiske iagttagers valg og beslutning. De indeholder hver deres specifikke modsætninger, og hver stil er på sin måde begrænset. Dette forhold lægger op til skribentens personlige valg.

Journalistens valg er så meget des mere krævet, da den traditionelle resultatjournalistik kan være i en krise. Siden sidst i 1980'erne viser forbruget af sportsmedierne i Danmark en nedgående tendens, mens den aktive deltagelse i idrætten vokser $\mathrm{i}$ nye retninger. ${ }^{44}$ Praktisk idrætsdeltagelse tenderer nu herhjemme til at overhale det passive sportsforbrug. Det er historisk nyt. Sportsjournalistens publikum er under forandring, og den traditionelle præstationsjournalistik ${ }^{45}$ er ikke længere automatisk udtryk for »folks interesse og gøren«.
Hvad modsætningerne angår, så rejser spørgsmålet sig, om der kunne identificeres nogle hovedmodsigelser inden for den folkelige idrætsfestkultur. Her kan man lade sig inspirere af iagttagere udefra, ligesom en landsstævne-journalist fra Aktuelt gjorde i 1998.

"Dette her er meget anderledes end alt, hvad vi kender til ... - her er alle sammen om tingene uanset alder og dygtighed. Det er meget imponerende. Man kan se, at sporten er baseret på deltagelse frem for resultater."

"Her er plads til den enkeltes stil og form. Og I tager det ikke så tungt, hvis den ydre fremtrceden ikke er perfekt. Vi har set folk trimle af måtten under et spring, men de slår bare ud med armene og lober videre $i$ stedet for at stå og gramme sig."

»På et gymnastikhold var der en kvinde, som gled. Deltageren foran hende tog sig tid til at vende sig om og se, om hun var okay - det var lige meget, at der r $\phi g$ et par trin. Selv de bedste griner affejl.«

Således udtalte en flok amerikanske antropologistuderende sig til dagbladet Aktuelt om deres oplevelse af landsstævnet i Silkeborg. Antropologens iagttagelser kan være meget sammensatte og præget af ambivalente følelser:

"Der er visse aspekter i gymnastikken, som faktisk kan minde om fascismen ideen om et sundt folk og det opdragende element $i$ sporten. Når man ser opvisningerne, minder det ind imellem om militcret med alle, der noesten marcherer $i$ takt ... Alle flagene giver også et indtryk af nationalisme.

»De bedste udøvere laver de svarere ovelser ind $i$ gruppen, så helheden be- 
står. Vi har også set en opvisning, hvor seks mennesker kom barende på en rund platform med en enkelt person på-men der kunne han kun stå, fordi de andre bar ham. Gruppen er det starke fundament. $\ll^{46}$

Individet, massen, gruppen - hvordan kan deres forhold, deres kvaliteter og modsætninger indfanges gennem journalisten diskurs? Og hvordan kan det specifikke komme til udtryk, som ligger i mangfoldigheden af menneskelig kropspraksis og udgør den folkelige fests rigdom?

På den ene side køres kameraets politik i stilling. Folk krystalliseres i masseoptrin med geometriske koreografier, som set ovenfra. Det viderefører fascismens visuelle strategi, der er mere end et spørgsmål om flag, ideologi og national retorik. Fascismens pointe var en blikkets politik. Demokrati og selvbestemmelse nedefra har ingen reel chance under fugleperspektivets dominans. Selvorganisering nedefra kan ikke fattes gennem underholdningens kamerablik.

På den anden side er kulturdemokratisk journalistik en ny udfordring. Fest, identitet og civilt samfund hænger sammen. Festivalen manifesterer i rum og tid, at mennesket ikke er alene i verden. Folk mødes i forskellighed og samspil. Anerkendelsen af det anderledes åbner op mod idrættens rigdom, hinsides standardisering og streamlining - idræt nedefra og indefra. Festjournalistik er en historisk-poetisk genre og en politisk opgave - eller et umuligt foretagende?

I hvert fald bliver relevante indre modsætninger af den folkelige fest, den folkelige idræt og dens selvorganisering i regi af DGI synlige. Og de indre modsigelser af en festjournalistik, som er mere end sportsjournalistik.

Journalistikkens bidrag til kropsligpraktisk demokrati kræver en følsom balance mellem objektivitet og subjektivitet. Begivenhedens »objektive« sider tenderer til at blive overbetonet gennem rekorderne af den olympiske type og gennem kameraets blik ned på masserne. Iagttagerens subjektive positionalitet og involvering er en vigtig del af spillet og af festen - men ikke det eneste og afgørende element. Intersubjektiviteten af, »hvad der sker « i krydsfeltet mellem kultur, politik og emotion, er den tredje i spillet, den dialogiske dimension.

Det er derfor, at den folkelige idræts fest ikke kan måles og vejes. Festen er en kulturel begivenhed, og »kultur er kamp - en kamp om at give hver eneste фjeblik af livet mere skønhed, mere mening ${ }^{4}{ }^{47}$

\section{Noter}

1. Brandt H. H. (28.6.2002), p. 5. Brandt H. H. (29.6.2002), p. 5.

2. Eichberg H. (1994).

3. Møller J. \& Andersen J. S. (red.) (Vejle, 1998). Andersen J. S. (red.) (Vejle, 2001). Andersen J. S. (red.) (Vejle, 2003).

4. Alkemeyer T. (1996).

5. Om Tyskland: Zieschang K. (1977). Neumann H. (1987). Om Schweiz: Triet M. \& Schildknecht P. (2002). Om de slaviske folk: Blecking D. (1990).

6. Madsen B. V. (2003).

7. Skot-Hansen D. (1998). Waade AM. (2002).

8. Lenskyj H. J. (2002).

9. Generel information om kilder: Anvendt er Polinfos presseomtale af landsstævnerne 1998 og 2002 i bladene: Aktuelt, Ekstra Bladet, Fyens Stiftstidende, Flensborg Avis, Fredericia Dagblad, Morgenavisen Jyllands-Posten, Politiken og Vejle Amts Folkeblad.

10. Jørgensen S. S. m.fl. (2002).

11. Hjelmgaard M. (2002). Hylbæk G (2002).

12. DGI presseinformation, 29.6.02. 
13. Hjelmgaard M. (2002).

14. Andersen J. S. (2002). Albret P. (2002).

15. Jennings A. \& Simson V. (1992). Jennings A. (1996). Jennings A. \& Sambrook C. (2000).

16. Kister T. \& Weinreich J. (red.) (2000).

17. Werge L. (2000).

18. Se fodnote 3 .

19. Radmer K. B (2002), p. 10-11. Bille S. (2003), p. 4.

20. Temahæfte af Ungdom \& Idrat nr. 21.

21. Landsstavne-avis - Bornholms Tidende nr. 1-4.

22. Larsen H. (red.) (2002a). Larsen H. (2002b).

23. F.eks. Bjerregaard H. (1935).

24. Steinert J. \& Ockert G. (red.) (2002).

25. Steinert J. \& Ockert G. (red.) (2002), pp. 26-31.

26. Se fodnote 22.

27. TV2 Sporten, Landsstævne 2002, Sammendrag (København 2002), video. - TV2 og DR-TV, Landsstævne 2002 Bornholm 27.-30. juni. Udsendelser fra L2002 (Vejle: DGI \& DDS, 2002), 4 videoer.

28. Leth J. (1976). Leth J. (1993). Leth J. (1996). Birkvad S. (1992).

29. F.eks. Gotfredsen S. (22.6.1998), p. 18. Gotfred- sen S. (29.7.1998), p. 16. Gotfredsen S. (31.12. 1998), pp. 20.22. Gotfredsen S. (18.5.2002), p. 12.

30. Ulrich T. (2002).

31. Madsen B. V. (2003), pp. 170-178.

32. Madsen B. V. (2003), pp. 208-249.

33. Albret P. i Dagbladet Information.

34. Albret P. (30.6.-2.7.1994). Albret P. (5.7.1994).

35. F.eks. Eichberg H. (1994b).

36. Kritisk om verdensholdet: Madsen B. V. (2003), pp. 251-325.

37. Om landsstævnet fra 1998 se Brandt K. (2001), pp. 67-174.

38. Jensen E. R. (2002), p. 18.

39. DGI (1998), pp. 163-78.

40. Seedorff P. P. (2002).

41. Hélias P. J. (1975, ny udg. 1987), p. 580.

42. Kuznezova Z. \& Milstein O. (1992), pp. 282-84.

43. Rüütel I. (2003).

44. Larsen K. (2003), pp. 72-97.

45. Jørgensen SS m.fl. (2002).

46. Britta Hansen B. (29.6.1998).

47. Girard A. (1973).

\section{Litteraturliste}

Albret P. Landsstavne - tre rapporter om den folkelige idrats store manifestation. I: Dagbladet Information d. 30.6.-2.7.1994.

Albret P. Kulturkamp - ja tak (leder). I: Dagbladet Information d. 5.7.1994.

Albret P. Gensyn med Bermuda-trekanten. I: Eichberg H. \& Madsen B. V. (red.) Idrættens enhed eller mangfoldighed, pp. 307-314 (Århus, 2002).

Alkemeyer T. Körper, Kult und Politik. Von der $» M u-$ skelreligion" Pierre de Coubertins zur Inszenierung von Macht in den Olympischen Spielen von 1936 (Frankfurt, 1996).

Andersen J. S. (red.). Play the Game - Reaching for Democracy in Sports. Stories from the second world conference of media professionals in a globalised sports society (Vejle, 2001).

Andersen J. S. Mediernes mulighed - fra passiv doping til aktivt demokrati. I: Eichberg H. \& Madsen B. V. (red.) Idrættens enhed eller mangfoldighed, pp. 295-306 (Århus, 2002).

Andersen J. S. (red.). Play the Game - Who's got the Power? Stories from the $3^{\text {rd }}$ international conference for media professionals in a globalised sports world (Vejle, 2003).

Bille S. Langt mellem gaesterne. Landsstavneområdet på Bornholm bruges kun i beskedent omfang. I: Ungdom \& idrat nr. 21 (2003), p. 4.

Birkvad S. Verden er leth. En bog om Jorgen Leths film og forfatterskab (Odense, 1992).

Bjerregaard H. Ollerup-Olympiaden $i$ Billeder og Tekst. Det nordiske Landsstavne 1935 (Svendborg, 1935).

Blecking D. Sokolfeste der Ruhrpolen. I: Teichler H. J. (red.) Sportliche Festkultur in geschichtlicher Perspektive, p. 34-48 (Clausthal-Zellerfeld, 1990).

Brandt H. H. På klippegrund; Ublu konkurrence. I: Jyllands-Posten d. 28.6.2002, p. 5.

Brandt H. H. På klippegrund; Et slag for den gode sag. I: Jyllands-Posten d. 29.6.2002, p. 5.

Brandt K. Rummer DGI's ideologi plads til idrcet? I: Hansen J. \& Skovgaard T. (red.) Sportens væsen og uvæsen. Idratshistorisk Årbog nr. 17, pp. 67-74 (Odense, 2001).

DGI. Hvidbog for Landsstavne '98 (Vejle, 1998).

DGI. Livsglade til Landsstavne. Bornholm 2002 Byger, blast og fest for fallesskabet - temahæfte af Ungdom \& Idrat nr. 21 (2002).

Eichberg H. Festen og idratten (Vejle, 1994a). 
Eichberg H. 'En herlig betankning' af 'mistankeliggфrende postulater' fra det 'kulturradikale spinatbed'. Stemmer om 'Idrcettens tredje vej' - i kronologisk orden. I: Hansen J. \& Trangbæk E. (red) Mellem terapi og bevægelse - Idrætshistoriens veje. Idrætshistorisk årbog nr. 10, pp. 161-167 (Odense, 1994b).

Girard A. Kulturpolitik - teori og praksis (København, 1973).

Gotfredsen S. Alverdens ånder $i$ aktion. Vis mig dit landshold, og jeg skal vise dig, hvem du er. I: Aktuelt d. 22.6.1998, p. 18.

Gotfredsen S. Den nye adel. Danmarks mest berømte idratsfolk udgфr en sarlig klasse $i$ samfundet. I: Aktuelt d. 29.7.1998, p. 16.

Gotfredsen S. Palnatokes sфnner. I: Aktuelt d. 31.12.1998, pp. 20-22.

Gotfredsen S. Fodboldkvinder er kunstige. I: Dagbladet Information d. 18.5.2002, p. 12.

Hansen B. Landsstavnet som feltstudium. I: Aktuelt d. 29.6. 1998 .

Hélias P. J. Le cheval d'orgueil. Mémoires d'un Breton du pays bigouden (Paris 1975, ny udg. 1987).

Hjelmgaard M. Medieomtale af Landsstavne 2002 (Observer Danmark, august 2002).

Hylbæk G. Samling af presseudklip om Landsstavnen (Vejle, 2002)

Jennings A. \& Simson V. The Lords of the Rings. Power, Money and Drugs in the Modern Olympics (London, 1992).

Jennings A. The New Lords of the Rings (London, 1996).

Jennings A. \& Sambrook C. The Great Olympic Swindle. When the World Wanted its Games Back (London, 2000).

Jensen E. R. Landsstavne med ridser i lakken. For meget fokus på gymnastik. I: Ungdom \& idræt nr. 25 (2002), p. 18.

Jørgensen S. S. m.fl. Industry or independence? Survey of the Scandinavian sports press. Særtryk af Monday morning (København, 2002).

Kister T. \& Weinreich J. (red). Der olympische Sumpf. Die Machenschaften des IOC (München/Zürich, 2000).

Kuznezova Z. \& Milstein O. Traditions of the Tatar Cultural Minority. I: Laine L. (red.): Sport and Cultural Minorities (Helsinki 1992).

Landsstavne-avis - Bornholms Tidende, nr. 1 (27. juni 2002).

Landsstavne-avis - Bornholms Tidende, nr. 2 (28. juni 2002).

Landsstavne-avis - Bornholms Tidende, nr. 3 (29. juni 2002).
Landsstavne-avis - Bornholms Tidende, nr. 4 (1. juli 2002).

Larsen H. (red.). Landsstavne 2002. Minder fra Bornholm (Rønne: Bornholms Tidende, 2002a).

Larsen H. (red.). Bornholm Landsstaevne 2002 (Vejle: DGI \& DDS, 2002b).

Larsen K. Idratsdeltagelse og idratsforbrug i Danmark (Århus, 2003).

Lenskyj H. J, The Best Olympics Ever? Social Impacts of Sydney 2000 (Albany, 2002).

Leth J. Det er ligesom noget i en drom. Udvalgte historier om cykelsport, 1970-75 (København, 1976).

Leth J. Michael Laudrup. En film bliver til (København, 1993).

Leth J. Den gule trøje i de høje bjerge. En personlig beretning over 25 år om Tour de France (2. udg.) (København, 1996).

Madsen B. V. Oplysning i bevagelse. Kultur, krop og demokrati i den folkelige gymnastik (Århus, 2003).

Medienspiegel zum Deutschen Turnfest Leipzig 2002 (Leipzig, 2002).

Møller J. \& Andersen J. S. (red.). Samfundets vagthund-eller tam entertainer? Inspiration til fremtidens sportsjournalistik (Vejle, 1998).

Neumann H. Deutsche Turnfeste. Spiegelbild der deutschen Turnbewegung (Wiesbaden, 1987).

Radmer K. B. Dagen derpå for stadion. DGI's stadion-byggeri møder kritik. I: Ungdom \& idrat $\mathrm{nr}$. 23 (2002), pp. 10-11.

Rüütel I. The singing revolution. Living traditional cultures and folklore movement in Estonia today. I: European Network of Traditional Music and Dance - Newsletter (2003) nr. 1. (www.eurotradmusic.net/news).

Seedorff P. P. Idratten i landskabet (Vejle \& København: DGI \& Landskabsværkstedet, 2002).

Skot-Hansen D. Holstebro i verden - verden i Holstebro. Kulturpolitik og -debat fra tresserne til $i$ dag (Århus, 1998).

Steinert J. \& Ockert G. (red.). Deutsches Turnfest Leipzig 2002. Hrsg. Deutscher Turner-Bund (Leipzig, 2002).

Triet M. \& Schildknecht P. Die Eidgenössischen Turnfeste 1832-2002. Streiflichter auf ein nationales Ereignis (Olten, 2002).

Ulrich T. Hvis - notater omkring et (idrcetsligt) faellesskab, det uindhentelige. I: Eichberg H. \& Madsen BV (red.) Idrættens enhed eller mangfoldighed, pp. 161-184 (Århus, 2002).

Ulrich T. Jazz, bold \& buddhisme (København, 2003) - redigeret af Lars Movin.

Waade A. M. Teater $i$ en teatraliseret samtidskultur. 
Resepsjonskulturelle mønstre $i$ aktuell scenekunst (Århus, 2002).

Werge L. Den olympiske bombe (Århus, 2000).

Zieschang K. Vom Schützenfest zum Turnfest. Die
Entstehung des Deutschen Turnfestes unter besonderer Berücksichtigung der Einflüsse von F. L. Jahn (Ahrensburg, 1977). 